\title{
"Patterns of corporate social responsibility of Ukrainian companies: clustering and improvement strategies for responsible activities"
}

\begin{tabular}{|c|c|}
\hline \multirow{6}{*}{ AUTHORS } & Victor Sukhonos ID https://orcid.org/0000-0001-5520-0227 \\
\hline & Inna Makarenko iD https://orcid.org/0000-0001-7326-5374 \\
\hline & R http://www.researcherid.com/rid/AAE-8453-2020 \\
\hline & Yulia Serpeninova (D https://orcid.org/0000-0002-4448-3484 \\
\hline & Oksana Drebot (D https://orcid.org/0000-0003-2681-1074 \\
\hline & Yoshihiko Okabe \\
\hline ARTICLE INFO & $\begin{array}{l}\text { Victor Sukhonos, Inna Makarenko, Yulia Serpeninova, Oksana Drebot and } \\
\text { Yoshihiko Okabe (2019). Patterns of corporate social responsibility of Ukrainian } \\
\text { companies: clustering and improvement strategies for responsible activities. } \\
\text { Problems and Perspectives in Management, } 17(2), 365-375 . \\
\text { doi:10.21511/ppm.17(2).2019.28 }\end{array}$ \\
\hline DOI & http://dx.doi.org/10.21511/ppm.17(2).2019.28 \\
\hline RELEASED ON & Tuesday, 11 June 2019 \\
\hline RECEIVED ON & Monday, 01 April 2019 \\
\hline \multirow[t]{2}{*}{ ACCEPTED ON } & Tuesday, 21 May 2019 \\
\hline & $((\mathrm{cc})$ EY \\
\hline LICENSE & $\begin{array}{l}\text { This work is licensed under a Creative Commons Attribution } 4.0 \text { International } \\
\text { License }\end{array}$ \\
\hline JOURNAL & "Problems and Perspectives in Management" \\
\hline ISSN PRINT & $1727-7051$ \\
\hline ISSN ONLINE & $1810-5467$ \\
\hline PUBLISHER & LLC "Consulting Publishing Company "Business Perspectives" \\
\hline FOUNDER & LLC "Consulting Publishing Company "Business Perspectives" \\
\hline
\end{tabular}

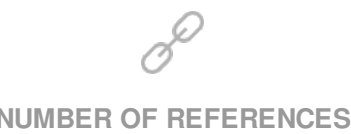

27

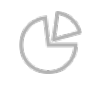

NUMBER OF FIGURES

0

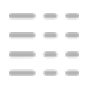

NUMBER OF TABLES

4

(C) The author(s) 2023. This publication is an open access article. 


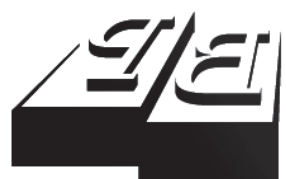

BUSINESS PERSPECTIVES

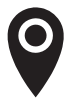

LLC "CPC "Business Perspectives" Hryhorii Skovoroda lane, 10, Sumy, 40022, Ukraine

www.businessperspectives.org

Received on: $1^{\text {st }}$ of April, 2019 Accepted on: $21^{\text {st }}$ of May, 2019

(c) Victor Sukhonos, Inna Makarenko, Yulia Serpeninova, Oksana Drebot, Yoshihiko Okabe, 2019

Victor Sukhonos, Professor, Sumy State University, Ukraine.

Inna Makarenko, Associate Professor, Sumy State University, Ukraine.

Yulia Serpeninova, Associate Professor, Sumy State University, Ukraine.

Oksana Drebot, Professor, Corresponding Member of NAAS, Institute of Agroecology and Environment Management of NAAS, Ukraine.

Yoshihiko Okabe, Associate Professor Kobe Gakuin University, Japan.

\section{(ㄷ)(ㄱ)}

This is an Open Access article, distributed under the terms of the Creative Commons Attribution 4.0 International license, which permits unrestricted re-use, distribution, and reproduction in any medium, provided the original work is properly cited.
Victor Sukhonos (Ukraine), Inna Makarenko (Ukraine), Yulia Serpeninova

(Ukraine), Oksana Drebot (Ukraine), Yoshihiko Okabe (Japan)

\section{PATTERNS OF CORPORATE SOCIAL RESPONSIBILITY OF UKRAINIAN COMPANIES: CLUSTERING AND IMPROVEMENT STRATEGIES FOR RESPONSIBLE ACTIVITIES}

\begin{abstract}
The variability of companies stakeholders' engagement forms, communication channels, approaches to disclosure of companies' corporate social responsibility (CSR) and strategies for CSR achievement cause the formation of benchmarks - patterns of responsible behavior of these companies. Determination of companies' CSR patterns plays is a ground of (plays a role or is a ground of) improving their strategies for responsible activities. These patterns were highlighted on the basis of comprehensive three-component indicator that illustrates the combination of parameters: models of companies' communication with stakeholders, approaches to the disclosure of information on CSR and strategies for incorporating CSR and Sustainable Development Goals. Positioning of 22 Ukrainian companies for the period 2005-2017 was made. Results of positioning allowed to determine such clusters of the companies in accordance with the pattern of responsible behavior as $\mathrm{A}$ - innovators, $\mathrm{B}$ - leaders, $\mathrm{C}$ - pursuer, D - followers, E - starters, F - outsiders; to develop the measures on the improvement of their CSR activity.
\end{abstract}

Keywords

corporate social responsibility, sustainability, CSR strategy, SDGs, responsible behavior

\section{JEL Classification Q01, Q16, O13, L66, M14, M40}

\section{INTRODUCTION}

Implementation of the corporate social responsibility (CSR) of companies by the multi-stakeholder approach is considered one of the important tools of their communication with stakeholders. At the same time, there is a significant variation in the choice of levels, boundaries, communication channels, principles of development of an engagement strategy (selecting the models of interaction of company with stakeholders, establishing an effective monitoring process, assessing the quality of communications with stakeholders based on CSR reporting (information disclosure)). The wide field of combinations of CSR strategies of companies, communications with stakeholders, approaches to CSR disclosure is additionally multiplied if companies incorporate the most relevant for stakeholders Sustainable Development Goals (SDGs) into the business strategy.

There is large piece of empirical evidence on each dimension:

1) integrating SDGs and CSR into companies' activity and disclosure (GRI, 2013; UNCTAD, 2016; Everaert et al., 2009; Ernst \& Young, 2012, 2016; Deloitte, 2011); 
2) investigation of CSR patterns (Amor-Esteban et al., 2018; De Villiers \& Marques, 2016; Yuan et al., 2011; Jamali et al., 2017; Skouloudis \& Evangelinos, 2012; Gjølberg, 2009);

3) models of stakeholders' engagement (Morsing \& Schulz, 2006; Galbreath, 2006; Lubin \& Esty, 2010; Frooman, 1997; Accountability, 2015).

But relevance of these studies and dimensions incorporation in Ukrainian companies' CSR activity is rather low because of low perception of sustainability ideology, CSR disclosure and SDGs wide spreading. This low level is the main obstacle for integrating CSR into business practice in Ukraine.

In this context, the aim of our study is to determine CSR patterns of companies and develop the of ways to improve them based on the abovementioned three dimensions - the choice of the most effective models of stakeholders' engagement and communicating with them, strategies for disclosing information on CSR, approaches to incorporating SDGs.

These patterns of companies' responsible behavior can be used as benchmark to understand the status and place of the company in competitive environment under sustainability conditions and improve their CSR strategies.

The study of these directions, based on the case of Ukrainian companies, requires special relevance due to the formation of corporate culture and CSR mechanisms of companies of different sectors of the economy (Bilan et al., 2019; Chortok et al., 2018), the lack of exemplary practices of interaction with stakeholders, building effective communications with them, low transparency of CSR of activity and insufficient progress in achieving the SDGs.

The remainder of the paper is structured as follows. Section 1 provides literature review and empirical evidence on companies' classification according to the degree of incorporation sustainability criteria into its activity. Section 2 provides characteristics of data used and research methodology design. Section 3 describes results obtained and final section contains some concluding remarks.

\section{LITERATURE REVIEW}

There is a clear understanding of CSR as a strategic direction of the company's activities and the instrument of stakeholder engagement in academia. Hancock (2001), Galbreath (2006), Lubin and Esty (2010) note that a company that ignores CSR negatively affects the well-being of its stakeholders, since CSR is a matter of strategy and a part of sustainability megatrend. Frooman (1997) emphasizes that the company has to take into account both the challenges of the CSR strategy implementation and search of practical means for implementation. Morsing and Schulz (2006) distinguish three fundamental models of communication with stakeholders on CSR (in ascending order of the degree of stakeholder engagement): model of stakeholder awareness, model of response to stakeholders and stakeholder engagement model. A similar approach by the levels of process of the stakehold- er engagement is also contained in AA 1000 SES standard. Along with this, the standard provides an indicative list of methods and channels of interaction with stakeholders in accordance with the engagement level (Accountability, 2015). Therefore, the number of companies' channels and methods of communication with stakeholders is so significant that it needs to be systematized to justify the most effective models of stakeholder engagement. Generalization of the company's channels of communication with stakeholders as one of the CSR activity dimensions is presented in Table 1.

The external presentation of the strategic orientations of companies on CSR in their reporting, prepared taking into account the information inquiries of the stakeholders on the achievement of the most meaningful SDGs by the company, are the second and third dimensions of companies' CSR activity. So, effective integration of SDGs and 
Table 1. The use of the companies' channels of communication with stakeholders in accordance with the models, levels and strategies of engagement

Source: Compiled by authors based on Accountability (2015).

\begin{tabular}{|c|c|c|c|}
\hline Model & Level & Strategy & Channels/methods \\
\hline \multirow{4}{*}{$\begin{array}{l}\text { One-way model - } \\
\text { the dissemination } \\
\text { of information from } \\
\text { the company to the } \\
\text { stakeholders }\end{array}$} & \multirow{4}{*}{ Passive level } & Lack of active communications & Letters, media, web-site \\
\hline & & $\begin{array}{l}\text { Monitoring - one-way communication } \\
\text { stakeholders - company }\end{array}$ & $\begin{array}{l}\text { Media, Internet tracking, company } \\
\text { reports, distributed through information } \\
\text { intermediaries }\end{array}$ \\
\hline & & $\begin{array}{l}\text { Defensive strategy - one-way } \\
\text { communication company - stakeholders }\end{array}$ & $\begin{array}{l}\text { Response to the pressure of regulators, } \\
\text { lobbying the interest, other defending actions } \\
\text { through social media }\end{array}$ \\
\hline & & $\begin{array}{l}\text { Communication strategy - one-way } \\
\text { communication company - stakeholders } \\
\text { without an invitation to response }\end{array}$ & $\begin{array}{l}\text { Bulletins, letters, different types of reporting, } \\
\text { web-sites, speeches, conferences and public } \\
\text { presentations }\end{array}$ \\
\hline \multirow{3}{*}{$\begin{array}{l}\text { Two-way } \\
\text { asymmetric model } \\
\text { - reactive response } \\
\text { to inquiries of } \\
\text { stakeholders }\end{array}$} & \multirow{3}{*}{$\begin{array}{l}\text { 1st level } \\
\text { Specific reactive } \\
\text { engagement } \\
\text { as a response } \\
\text { to pressure or } \\
\text { changes }\end{array}$} & $\begin{array}{l}\text { Transaction strategy - limited two-way } \\
\text { communication within monitoring activities } \\
\text { in accordance with the terms of the } \\
\text { agreement }\end{array}$ & $\begin{array}{l}\text { Public and private partnership, private } \\
\text { financial initiatives, grant activities and } \\
\text { reporting on them }\end{array}$ \\
\hline & & $\begin{array}{l}\text { Counseling strategy - limited two-way } \\
\text { communication: the company asks a } \\
\text { question - the stakeholders answer }\end{array}$ & $\begin{array}{l}\text { Surveys, focus groups, seminars, meetings } \\
\text { with individual stakeholders, public meetings, } \\
\text { research, advisory committees }\end{array}$ \\
\hline & & $\begin{array}{l}\text { Negotiation strategy - limited two-way } \\
\text { communication: discussion of specific issues } \\
\text { with purpose to reach a consensus }\end{array}$ & Collective agreements with staff \\
\hline \multirow{3}{*}{$\begin{array}{l}\text { Two-way model } \\
\text { of the dialogue } \\
\text { with stakeholders } \\
\text { - proactive } \\
\text { engagement of } \\
\text { stakeholders into } \\
\text { cooperation }\end{array}$} & \multirow{2}{*}{$\begin{array}{l}\text { 2nd level Planned } \\
\text { and systematic } \\
\text { engagement for } \\
\text { risk and revenue } \\
\text { management }\end{array}$} & $\begin{array}{l}\text { Engagement strategy - two-way or } \\
\text { multilateral communication, which } \\
\text { covers many issues, but the company and } \\
\text { stakeholders operate independently }\end{array}$ & $\begin{array}{l}\text { Multi-stakeholder forums, advisory panels, } \\
\text { participatory decision-making process, } \\
\text { consensus building processes, focus groups, } \\
\text { online methods of interaction }\end{array}$ \\
\hline & & $\begin{array}{l}\text { Collaboration strategy: two-way or } \\
\text { multilateral communication - joint learning, } \\
\text { joint activities and decision-making process }\end{array}$ & $\begin{array}{l}\text { Joint projects, joint events, partnerships, } \\
\text { multi-stakeholder initiatives, online } \\
\text { collaboration platforms }\end{array}$ \\
\hline & $\begin{array}{l}\text { 3rd level } \\
\text { Integration } \\
\text { of strategic } \\
\text { engagement } \\
\text { for company's } \\
\text { sustainability }\end{array}$ & $\begin{array}{l}\text { Broadening capabilities - a new strategy } \\
\text { for communication and accountability: } \\
\text { decision-making is delegated to } \\
\text { stakeholders; stakeholders determine the } \\
\text { strategy and agenda of the company }\end{array}$ & $\begin{array}{l}\text { Integration of stakeholders into the } \\
\text { management structure of the company, its } \\
\text { business strategy and operational tactics }\end{array}$ \\
\hline
\end{tabular}

CSR into companies' activity and disclosure is a crucial point for companies' good positioning in competitive business environment. This statement is an object of discussion in studies by GRI (2013), UNCTAD (2016), Everaert et al. (2009).

Integral patterns of companies' behavior regarding their commitment to sustainability and CSR were investigated from the standpoint of country legal system in Amor-Esteban et al. (2018); from the standpoint of the level of CSR disclosure and country democracy freedom - in De Villiers and Marques (2016); from the standpoint of the social norm - in Lawrence et al. (2013) and from the standpoint of environmental legal norm - in Glennie and Lodhia (2013); from the standpoint of the type of implementation of CSR in company's organizational structure - in Yuan et al. (2011). Patterns of corporate social irresponsibility were analyzed in Sulphey (2017) in opposite way to CSR, as well as shift in CSR model from corporatism to socialized capitalism that is presented in Khan et al. (2015).
CSR patterns in developing countries (China, India, Nigeria and Lebanon) were observed in Jamali et al. (2017) in the context of cultural and institutional factors, stimulated responsible business activity; in 18 European countries, North America, Japan and Australia - in Amor-Esteban et al. (2017) in the context of the influence of the cultural system on degree of responsibility of business behavior and patterns; cross-country specific cultural environment - in Skouloudis and Evangelinos (2012); in 20 OECD countries - in Gjølberg (2009) in the context of CSR index construction.

Many channels for communicating with stakeholders, methods and strategies for interacting with them against the background of a significant number of strategies to incorporate the SDGs to a company's activities under sustainability conditions and highlighting the progress in their achievement in CSR reporting create the necessity to form benchmarks - patterns of responsible behavior of companies - in order to understand the 
status and place of the company in competitive environment under sustainability conditions and improve their CSR strategies.

A number of studies indicate different approaches to the companies' positioning according to the degree of incorporation of sustainability criteria into activity strategies and tools for the CSR strategy implementation. But these criteria and tools are puzzled in academia, as well as in professional accounting companies' researches.

Hancock (2001), Lubin and Esty (2010) defined such companies' CSR patterns as losers, defenders, dreamers, winners, only based on their respond to the challenges and megatrends of sustainability and SDGs.

Ernst and Young (2012) defined such companies' CSR patterns as non-reporting companies, middle pack companies, companies-differentiators by the degree of integration of the sustainability reporting strategy into the management structure. In further research, Ernst and Young (2016) describe companies - starters, companies in the middleof-the-pack, front-runners companies - by the degree of disclosure of information on CSR and sustainability challenges to stakeholders. Deloitte (2011) uses the sustainability maturity stage as a criterion for defining companies' followers, mature companies and companies' leaders.

In our study, we try to avoid sustainability criterion puzzling and integrate a number of relevant abovementioned parameters for Ukrainian companies' CSR patterns desceiption. Despite the low degree of dissemination of CSR in Ukraine compared to developed countries (see for details Sukhonos et al., 2018, p. 133; Sukhonos \& Makarenko, 2017, p. 169), the Ukrainian companies have gained some experience in implementing responsible behavior strategies and disclosing information about it. But this experience is rather poor and clear CSR benchmark can be the trigger for better CSR perception and competitive business environment development. So, we try to take into account the models of companies' communication with stakeholders, approaches to the disclosure of information on CSR and strategies for incorporating CSR and SDGs to CSR patterns, determining and improving companies' responsible behavior.

\section{DATA AND METHODOLOGY}

To determine CSR patterns of companies as benchmarks to understand their status and place in competitive environment under sustainability and improve their CSR strategies, we use the following three dimensions for companies' positioning and clustering:

1) exploring a variety of communication models for stakeholders' engagement;

2) disclosing information by companies;

3) incorporating the SDGs in their work.

It was suggested to use these directions as the basis for the methods by the responsible behavior patterns. Period of the study covers 2005-2017, as it is available time interval during which the publication of CSR reports by 22 Ukrainian companies of various sectors of the economy (metal products, food and beverage products, financial and banking service, etc.) in various formats was carried out.

The study covers these 22 companies, 64 reports of which are published in the Sustainability Disclosure Database GRI and 18 reports on corporate sites for the entire study period (including 2017). An analysis of the publication activity of companies showed that $36 \%$ of companies of the total volume ceased to submit CSR reports during earlier periods - until 2014 (for example, PJSC Kyivstar - in 2012, PJSC Mondelez Ukraine - in 2013) and do not submit reports regularly. Taking into account this fact, the object of the study of the strategies of companies' responsible behavior are the latest reports published by each company.

As a methodology of conducting the study we propose to choose the laws of combinatories to determining each company's position in a three-dimensional matrix with coordinates $G \in\{x ; y ; z\}$, which represents the level of incorporation of the specified parameters of the company's CSER activities and define the responsible behavior pattern.

These parameters were selected from year by CSER report of each company on the basis of content analysis tools. Searching the information in the published reports of each company was carried out according to the bilingual principle (Ukrainian and English) by the following key categories: 
- generic category: stakeholders (species categories - models, interaction channels, strategies, stakeholder engagement, interaction panels, reporting verification by stakeholders, participation in decision-making);

- generic category: SDGs (species categoriesstrategies for incorporation of the SDGs, strategy of value formation by company, relevant SDGs progress in achievement of SDGs.

Based on the results of the content analysis, we define such pattern parameters as models of their communication and stakeholders' engagement (parameter $x$ ), disclosure of CSR reporting (parameter $y$ ) and incorporation of the SDGs to the company's strategy (parameter $z$ ). Depending on the values of these three parameters, it was suggested to determine the company's position in a three-dimensional matrix with coordinates $\mathrm{G} \in\{\mathrm{x}$; $y ; z$, which take values from 1 to 3 in ascending order of the level of incorporation of the specified parameters of the company's activities (Appendix A). Each parameter of the indicator is determined by the following gradations in units:

- parameter x (integrated engagement model - 3; planned and systematic model -2 ; passive one-way model - 1);

- parameter y (strategies of inclusive disclosure - 3; disclosure of the most significant inquiries -2 ; strategy of minimum information disclosure -1);

- parameter $\mathrm{z}$ (integration into the strategy of value formation - 3; implementation of relevant SDGs - 2; incorporating the overall context of sustainability -1 ).

The value of the complex three-component indicator $\mathrm{G}$ varies within the established limits (according to the laws of combinatories, the minimum value of the sum of the parameters of the indicator equals 3 units; the maximum value equals 9 units) by the following levels:

- $\Sigma=8-9$ units $(\mathrm{G} \in\{3 ; 3 ; 3\} ; \mathrm{G} \in\{2 ; 3 ; 3\} ; \mathrm{G} \in\{3 ; 2 ; 3\}$; $\mathrm{G} \in\{3 ; 3 ; 2\})$;

- $\quad \sum=7$ units $(\mathrm{G} \in\{3 ; 1 ; 3\} ; \mathrm{G} \in\{1 ; 3 ; 3\} ; \mathrm{G} \in\{3 ; 3 ; 1\} ; \mathrm{G}$ $\in\{2 ; 2 ; 3\} ; \mathrm{G} \in\{3 ; 2 ; 2\} ; \mathrm{G} \in\{2 ; 3 ; 2\}) ;$

$\Sigma=6$ units $(\mathrm{G} \in\{2 ; 2 ; 2\} \mathrm{G} \in\{3 ; 2 ; 1\} ; \mathrm{G} \in\{1 ; 2 ; 3\} ; \mathrm{G}$ $\in\{1 ; 3 ; 2\} ; \mathrm{G} \in\{2 ; 1 ; 3\} ; \mathrm{G} \in\{2 ; 3 ; 1\} ; \mathrm{G} \in\{3 ; 1 ; 2\}) ;$

- $\quad \Sigma=5$ units $(\mathrm{G} \in\{1 ; 2 ; 2\} ; \mathrm{G} \in\{1 ; 1 ; 3\} ; \mathrm{G} \in\{1 ; 3 ; 1\} ; \mathrm{G}$ $\in\{3 ; 1 ; 1\} ; \mathrm{G} \in\{2 ; 1 ; 2\} ; \mathrm{G} \in\{2 ; 2 ; 1\}) ;$

- $\Sigma=4$ units $(G \in\{1 ; 2 ; 1\} ; G \in\{1 ; 1 ; 2\} ; G \in\{2 ; 1 ; 1\}) ;$

- $\quad \sum=3$ units $(\mathrm{G} \in\{1 ; 1 ; 1\})$.

According to the values of the indicator $G$ in a three-dimensional matrix, it is possible to cluster companies according to the decreasing principle: from A to F, which represent patterns of companies' responsible behavior.

\section{RESULTS}

The positioning of companies according to the values of the indicator $G$ in a three-dimensional matrix allows to cluster them according to the decreasing principle, where A - companies that are characterized by the maximum value of the indicator; F - companies that are characterized by the minimum value of the indicator. As can be seen from Appendix A, there is a context of sustainability and information is disclosed on all dimensions and Environmental, Social and Governance (ESG) criteria (81.8\% of the analyzed companies) in the reports of most companies. In addition, $59.1 \%$ of companies' reports are formed taking into account the information inquiries of their stakeholders with different levels of significance. At the same time, only $18 \%$ of the reports of the studied companies are characterized by the availability of verification (by internal or external auditors, stakeholders).

Regarding the obtained values of the parameter $x$, it should be noted that $72 \%$ of studied companies use the two-way dialogue strategy (both asymmetric and proactive types) during the process of cooperation with stakeholders. According to the parameter $y$, half $(50 \%)$ of the companies disclose the most significant inquiries of stakeholders in their reports, without taking into account the integrated format of information presentation. 
Table 2. Map of measures on the improvement of the strategies of responsible behavior by their patterns in quantitative assessment

Source: Compiled by the authors.

\begin{tabular}{|c|c|c|c|}
\hline $\begin{array}{l}\text { Class/ } \\
\text { pattern }\end{array}$ & Value of indicator $\mathbf{G}$ & Companies & Basic areas for strategy improvement \\
\hline A-innovators & $\begin{aligned} \mathrm{G} & \in\{3 ; 3 ; 3\} \\
\mathrm{G} & \in\{2 ; 3 ; 3\} \\
\mathrm{G} & \in\{3 ; 2 ; 3\} \\
\mathrm{G} & \in\{3 ; 3 ; 2\} \\
\sum & =8-9 \text { points }\end{aligned}$ & $\begin{array}{l}\text { Coca-Cola Group Ukraine } \\
\text { (2016-2017), } \\
\text { PJSC ArcelorMittal Kryvyi Rih (2016), } \\
\text { PJSC Concern Galnaftogaz (2016) }\end{array}$ & $\begin{array}{l}\text { - Continued implementation of CSR by inclusive } \\
\text { strategies }\end{array}$ \\
\hline B - leaders & $\begin{array}{l}G \in\{3 ; 1 ; 3\} \\
G \in\{1 ; 3 ; 3\} \\
G \in\{3 ; 3 ; 1\} \\
G \in\{2 ; 2 ; 3\} \\
G \in\{3 ; 2 ; 2\} \\
G \in\{2 ; 3 ; 2\} \\
\sum=7 \text { points }\end{array}$ & $\begin{array}{l}\text { BDO Ltd (2016), } \\
\text { DTEK Holding (2016), } \\
\text { Ernst \&Young Ltd. - Audit services } \\
\text { (2015-2016), } \\
\text { Kernel Holding (2016), } \\
\text { PJSC Obolon (2016) }\end{array}$ & $\begin{array}{l}\text { - Shift in focus towards significant information } \\
\text { inquires of stakeholders during CSR } \\
\text { implementation } \\
\text { Broadening the ways of interaction with } \\
\text { stakeholders }\end{array}$ \\
\hline C-pursuer & $\begin{array}{l}G \in\{2 ; 2 ; 2\} \\
G \in\{3 ; 2 ; 1\} \\
G \in\{1 ; 2 ; 3\} \\
G \in\{1 ; 3 ; 2\} \\
G \in\{2 ; 1 ; 3\} \\
G \in\{2 ; 3 ; 1\} \\
G \in\{3 ; 1 ; 2\} \\
\Sigma=6 \text { points }\end{array}$ & $\begin{array}{l}\text { PJSC Myronivskyi khliboprodukt } \\
\text { (MHP) KPMG-Ukraine Ltd., } \\
\text { JSC KPMG Audit (2016) }\end{array}$ & $\begin{array}{l}\text { - Integration of SDGs to the strategy of company } \\
\text { value formation } \\
\text { Broadening the ways of interaction with } \\
\text { stakeholders }\end{array}$ \\
\hline$D$ - followers & $\begin{array}{l}G \in\{1 ; 2 ; 2\} \\
G \in\{1 ; 1 ; 3\} \\
G \in\{1 ; 3 ; 1\} \\
G \in\{3 ; 1 ; 1\} \\
G \in\{2 ; 1 ; 2\} \\
G \in\{2 ; 2 ; 1\} \\
\sum=5 \text { points }\end{array}$ & $\begin{array}{l}\text { PJSC Beer-nonalcoholic brewery } \\
\text { "Slavutych" (2015); Metinvest } \\
\text { Holding (2014); JSC Dniprospetsstal } \\
\text { (2013-2014); PJSC Platinum } \\
\text { Bank (2014); JSC System Capital } \\
\text { Management (2015) }\end{array}$ & $\begin{array}{l}\text { - Integration of SDGs to the strategy of company } \\
\text { value formation } \\
\text { Increased interaction with stakeholders, } \\
\text { enhanced communications }\end{array}$ \\
\hline $\mathrm{E}$ - starters & $\begin{array}{l}\mathrm{G} \in\{1 ; 2 ; 1\} \\
\mathrm{G} \in\{1 ; 1 ; 2\} \\
\mathrm{G} \in\{2 ; 1 ; 1\} \\
\Sigma=4 \text { points }\end{array}$ & $\begin{array}{l}\text { "Astarta-Kyiv" agro-industrial holding } \\
\text { (2016), PJSC UniCredit Bank (2015), } \\
\text { Volia-Cable Ltd. (2016) }\end{array}$ & $\begin{array}{l}\text { Orientation of the CSR strategy to the most } \\
\text { significant inquiries of the stakeholders } \\
\text { Incorporating the most relevant SDGs in CSR } \\
\text { of activity } \\
\text { Broadening the ways of stakeholder } \\
\text { engagement }\end{array}$ \\
\hline F-outsiders & $\begin{array}{l}\mathrm{G} \in\{1 ; 1 ; 1\} \\
\Sigma=3 \text { points }\end{array}$ & $\begin{array}{l}\text { PJSC Mondelez Ukraine (2014); } \\
\text { LVN Limited (TM Nemiroff) (2010); } \\
\text { ViDi Group Holding (2005-2010); } \\
\text { JSC Kyivstar (2015-2016); }\end{array}$ & $\begin{array}{l}\text { - Conducing a SWOT analysis of the company } \\
\text { under sustainability conditions } \\
\text { Development of an action plan on } \\
\text { incorporation of the SDGs, interaction with } \\
\text { stakeholders }\end{array}$ \\
\hline
\end{tabular}

Only companies of A and B clusters are characterized by integrated information disclosure taking into account value formation strategies at different horizons, specifications of the most relevant SDGs in their activities and the results of interaction with stakeholders.

By parameter $z$, most of the companies declare the compliance of their activities with 10 principles of the United Nations Global Compact and are its signatories. However, the incorporation of the SDGs into the strategy of value formation by companies (parameter $\mathrm{z}$ ) is least estimated among other parameters, and the implementation strategies of the SDGs themselves have not become a part of their current activities.
The exceptions are "company - leaders" and "innovators". The qualitative characteristic of the clusters in accordance with the studied parameters are disclosed in Appendix B.

A qualitative assessment of the parameters of the three-component indicator allowed to develop a map of measures for comprehensive improvement of the strategies of responsible behavior of companies based on incorporation of the SDGs, stakeholders' engagement and communication with them for each of the patterns (Table 2).

Such approach allows the following: at company level - to understand their capabilities, risks, status at the benchmark level, necessary efforts to move 
to a higher level (while conducting SWOT analysis) and the effect of stakeholders' engagement (while implementing strategies for doing business and communicating with stakeholders); at the level of individual groups of stakeholders - to form a inte- grated approach to incorporate the SDGs into the communication strategies for sustainability and doing business, stakeholders engagement and confirming the reliability of reporting in their favor from internal and independent auditors.

\section{CONCLUSION}

A significant number of channels for companies communication with stakeholders, ways of disclosing information on CSR are multiplied with the strategies of incorporating the SDGs into the current activities of such companies and create the necessity to form benchmarks - patterns of responsible behavior of companies to understand the status and place of the company in competitive environment under sustainability conditions.

There are different puzzled approaches to the companies' positioning according to the degree of responsible behavior. We try to avoid sustainability criterion puzzling (Hancock, 2001; Lubin \& Esty, 2010; Ernst \& Young, 2012, 2016; Deloitte, 2011) and integrate a number of relevant parameters for Ukrainian companies' CSR patterns, as well as models of companies' communication with stakeholders, approaches to the disclosure of information on CSR and strategies for incorporating CSR and SDGs.

According to the results of the content analysis of 82 CSR reports of 22 Ukrainian companies for the period 2005-2017, there were determined the strategies of companies taking into account the abovementioned parameters: the models of their interaction with stakeholders (parameter $x$ ), communication with them based on CSR reports (parameter $y$ ) and incorporation of the SDGs into the company's strategy (parameter $z$ ). Depending on the values of these three parameters, it was suggested to determine the company's position in the three-dimensional matrix.

The positioning of companies according to the values of the indicator $\mathrm{G}$ in three-dimensional matrix allows clustering them by the decreasing principle and defining 6 patterns of companies' responsible behavior.

The analysis of these patterns allowed developing a map of measures for the comprehensive improvement of the strategies of companies' responsible behavior based on incorporation of the SDGs, stakeholders' engagement and communication with them for each of the patterns.

The practical significance of the obtained results can be differentiated at the company's level - it allows to determine the risks and opportunities in the field of CSR activities; at the stakeholders' level - to get a tool for analyzing CSR of companies and the effectiveness of communication with them.

\section{ACKNOWLEDGEMENT}

Comments from the Editor and anonymous referees have been gratefully acknowledged. Inna Makarenko gratefully acknowledges financial support from the Ministry of Education and Science of Ukraine "Corporate social and environmental responsibility for sustainable development: stakeholders partnership in the real, financial and public sectors of the economy" (0117U003933). 


\section{REFERENCES}

1. Accountability. (2015). AA1000SES. Retrieved from https://www.accountability.org/ wp-content/uploads/2016/10/ AA1000SES_2015.pdf

2. Amor-Esteban, V., GalindoVillardón, P., \& García-Sánchez, I. M. (2017). Cultural values on CSR patterns and evolution: A study from the biplot representation. Ecological Indicators, 81, 1829. https://doi.org/10.1016/j. ecolind.2017.05.051

3. Amor-Esteban, V., García-Sánchez, I. M., \& Galindo-Villardón, P. (2018). Analyzing the Effect of Legal System on Corporate Social Responsibility (CSR) at the Country Level, from a Multivariate Perspective. Social Indicators Research, 140(1), 435452. https://doi.org/10.1007/ s11205-017-1782-2

4. Bilan, Y., Streimikiene, D., Vasylieva, T., Lyulyov, O., Pimonenko, T., \& Pavlyk, A. (2019). Linking between renewable energy, $\mathrm{CO} 2$ emissions, and economic growth: Challenges for candidates and potential candidates for the EU membership. Sustainability, 11(6), 1528. http://dx.doi.org/10.3390/ su11061528

5. Chortok, Y., Yevdokymova, A., \& Serpeninova, Y. (2018). Formation of the mechanism of corporate social and environmental responsibility of the trading company. Journal of Environmental Management and Tourism, 9(5), 10111018. https://doi.org/10.14505// jemt.9.5(29).13

6. De Villiers, C., \& Marques, A. (2016). Corporate social responsibility, country-level predispositions, and the consequences of choosing a level of disclosure. Accounting and Business Research, 46(2), 167-195. https://doi.org/10.1080/00014788. 2015.1039476

7. Deloitte. (2011). IIA: The role of internal audit in non-financial and Integrated Reporting. Retrieved from http://integratedreporting. org/resource/the-role-of-internalaudit-in-non-financial-and-integrated-reporting/
8. Ernst and Young. (2012) Sustainability reporting: meeting stakeholder demand for relevant, credible and reliable information. Retrieved from http://www. ey.com/Publication/vwLUAssets/ Sustainability-reporting-Meetingstakeholder-demand/\$File/ Sustainability-reporting-Meetingstakeholder-demand.pdf

9. Ernst and Young. (2016) Road to reliable non-financial reporting. Retrieved from http://www. ey.com/Publication/vwLUAssets/EY-ccass-road-to-reliablenonfinancial-reporting/\$FILE/ EY-ccass-road-to-reliable-nonfinancial-reporting.pdf

10. Everaert, P., Bouten, L., Van Liedekerke, L., De Moor, L., \& Christiaens, J. (2009). Discovering patterns in corporate social responsibility (CSR) reporting: A transparent framework based on the Global Reporting Initiative's (GRI) Sustainability Reporting Guidelines (Working Papers). Faculty of Economics and Business Administration, Ghent University. Retrieved from https://www.researchgate.net/ publication/46443364_Discovering_patterns_in_corporate_social_ responsibility_CSR_reporting_A_ transparent_framework_based_ on_the_Global_Reporting_Initiativeas_GRI_Sustainability_Reporting_Guidelines

11. Frooman, J. (1997). Socially irresponsible and illegal behavior and shareholder wealth: A metaanalysis of event studies. Business \& Society, 36(3), 221-249.

12. Galbreath, J. (2006). Corporate social responsibility strategy: strategic options, global considerations. Corporate Governance: The international journal of business in society, 6(2), 175-187.

13. Gjølberg, M. (2009). Measuring the immeasurable?: Constructing an index of CSR practices and CSR performance in 20 countries. Scandinavian Journal of Management, 25(1), 10-22. https://doi.org/10.1016/j.scaman.2008.10.003
14. Glennie, M., \& Lodhia, S. (2013). The influence of internal organizational factors on corporate-community partnership agendas: An Australian case study. Meditari Accountancy Research, 21(1), 52-67.

15. Global Reporting Initiative (2013). Sustainability Topics for Sectors: What do stakeholders want to know? Retrieved from http://www. globalreporting.org/resourcelibrary/sustainability-topics.pdf.

16. Hancock, H. (2001). Corporate Social Responsibility and Strategy. Retrieved from https://www.ibe. org.uk/userassets/otherpdfs/ugwinner2015.pdf

17. Jamali, D., Karam, C., Yin, J., \& Soundararajan, V. (2017). CSR logics in developing countries: Translation, adaptation and stalled development. Journal of World Business, 52(3), 343-359. https:// doi.org/10.1016/j.jwb.2017.02.001

18. Khan, N., Kakabadse, A., \& Kakabadse, N. (2015). Spirit of corporate social responsibility transforming from corporatism to socialized capitalism. Problems and Perspectives in Management, 13(1), 85-95. Retrieved from https://businessperspectives.org/ images/pdf/applications/publishing/templates/article/assets/6335/ PPM_2015_01_Khan.pdf

19. Lawrence, S. R., Botes, V., Collins, E., \& Roper, J. (2013). Does accounting construct the identity of firms as purely self-interested or as socially responsible? Meditari Accountancy Research, 21(2), 144160.

20. Lubin, D., \& Esty, D. (2010). The Sustainability Imperative. Harvard Business Review. Retrieved from https://hbr.org/2010/05/the-sustainability-imperative

21. Morsing, M., \& Schultz, M. (2006). Corporate social responsibility communication: stakeholder information, response and involvement strategies. Business Ethics: A European Review, 15(4), 323-338. 
22. Skouloudis, A., \& Evangelinos, K. (2012). A research design for mapping national CSR terrains. International Journal of Sustainable Development and World Ecology, 19(2), 130-143. https://doi.org/10.1080/13504509. 2011.606338

23. Sukhonos, V., \& Makarenko, I. (2017). Sustainability reporting in the light of corporate social responsibility development: economic and legal issues. Problems and Perspectives in Management, 15(1-1), 166174. https://doi.org/10.21511/ ppm.15(1-1).2017.03
24. Sukhonos, V., Makarenko, I., Serpeninova, Yu., \& Qasimova, G. (2018). Classification and prioritization of stakeholders' information requests according to Sustainable Development Goals: case of cross-sector partnership in Ukrainian food production industry. Problems and Perspectives in Management, 16(4), 126-140. https://doi. org/10.21511/ppm.16(4).2018.12

25. Sulphey, M. (2017). Corporate Social Responsibility or Corporate Social Irresponsibility: where should be the focus? Problems and Perspectives in Management, 15(4), 293 -

301. https://doi.org/10.21511/ ppm.15(4-1).2017.13

26. UNCTAD. (2016). Enhancing the role of reporting in attaining the Sustainable Development Goals: Integration of environmental, social and governance information into company reporting. Geneva: UNCTAD secretariat.

27. Yuan, W., Bao, Y., \& Verbeke, A. (2011). Integrating CSR Initiatives in Business: An Organizing Framework. Journal of Business Ethics, 101, 75-92. https://doi. org/10.1007/s10551-010-0710-z 
Table A1. The positioning of the Ukrainian companies by the parameters of information disclosure and by three-component indicator in 2005-2017

\begin{tabular}{|c|c|c|c|c|c|c|c|c|c|c|}
\hline Company & $\begin{array}{l}\text { Reporting } \\
\text { period }\end{array}$ & Standard of report & \begin{tabular}{|c|} 
Inquiries of \\
stakeholders
\end{tabular} & Verification & $\begin{array}{l}\text { Measurement } \\
\text { and criteria }\end{array}$ & $\begin{array}{c}\text { Parameter } \\
\mathbf{x}\end{array}$ & $\begin{array}{c}\text { Parameter } \\
\mathbf{y}\end{array}$ & $\begin{array}{c}\text { Parameter } \\
z\end{array}$ & $\begin{array}{l}\text { Indicator } \\
\text { G, unit }\end{array}$ & Pattern \\
\hline PJSC Arcelor Mittal Kryvyi Rih & 2016 & $\mathrm{GRI}-\mathrm{G} 4$ & + & + & ESG & 2 & 3 & 3 & 8 & Innovators \\
\hline $\begin{array}{l}\text { "Astarta-Kyiv" agro-industrial } \\
\text { holding }\end{array}$ & 2016 & Non-GRI & - & - & ESG & 1 & 2 & 1 & 4 & Starters \\
\hline BDO Ltd. & 2016 & $\mathrm{GRI}-\mathrm{G} 4$, IIRC & + & + & ESG & 2 & 2 & 3 & 7 & Leader \\
\hline $\begin{array}{l}\text { Carlsberg Ukraine (PJSC Beer- } \\
\text { nonalcoholic brewery "Slavutych") }\end{array}$ & 2015 & Non-GRI & - & - & ESG & 1 & 2 & 2 & 5 & Followers \\
\hline Coca-Cola Ukraine Group & $2016-2017$ & GRI Standards & + & - & ESG & 3 & 3 & 3 & 9 & Innovators \\
\hline JSC Dniprospetsstal & $2013-2014$ & GRI-G3 & + & - & ESG & 2 & 2 & 1 & 5 & Followers \\
\hline DTEK Holding & 2016 & $\mathrm{GRI}-\mathrm{G} 4$ & + & + & ESG & 2 & 2 & 3 & 7 & Leader \\
\hline Ernst \& Young Ltd. - Audit services & $2015-2016$ & $\mathrm{GRI}-\mathrm{G} 4$ & + & - & ESG & 2 & 2 & 3 & 7 & Leader \\
\hline PJSC Concern Galnaftogaz & 2016 & $\mathrm{GRI}-\mathrm{G} 4$ & + & + & ESG & 3 & 3 & 3 & 9 & Innovators \\
\hline Kernel Holding & 2016 & $\mathrm{GRI}-\mathrm{G} 4$ & + & + & ESG & 3 & 3 & 1 & 7 & Leader \\
\hline $\begin{array}{l}\text { KPMG -Ukraine Ltd., } \\
\text { JSC KPMG Audit }\end{array}$ & 2016 & Non-GRI & + & - & s & 2 & 1 & 3 & 6 & Pursuer \\
\hline JSC Kyivstar & $2015-2016$ & Non-GRI & - & - & S & 1 & 1 & 1 & 3 & Outsiders \\
\hline Metinvest Holding & $2013-2014$ & $\mathrm{GRI}-\mathrm{G} 4$ & - & - & ESG & 2 & 2 & 1 & 5 & Followers \\
\hline $\begin{array}{l}\text { PJSC Myronivskyi khliboprodukt } \\
\text { (MHP) }\end{array}$ & 2016 & $\mathrm{GRI}-\mathrm{G} 4$ & + & - & ESG & 3 & 2 & 1 & 6 & Pursuer \\
\hline PJSC Mondelez Ukraine & 2013 & Non-GRI & - & - & ESG & 1 & 1 & 1 & 3 & Outsiders \\
\hline LVN Limited (TM Nemiroff) & 2010 & Non-GRI & - & - & ESG & 1 & 1 & 1 & 3 & Outsiders \\
\hline PJSC Obolon & $2015-2016$ & $\mathrm{GRI}-\mathrm{G} 4$ & + & - & ESG & 3 & 2 & 2 & 7 & Leader \\
\hline PJSC Platinum Bank & 2014 & $\mathrm{GRI}-\mathrm{G} 4$ & + & - & ESG & 2 & 2 & 1 & 5 & Followers \\
\hline JSC System Capital Management & 2015 & GRI - G3 & - & - & ESG & 2 & 2 & 1 & 5 & Followers \\
\hline PJSC UniCredit Bank & 2015 & Non-GRI & - & - & ESG & 2 & 1 & 1 & 4 & Starters \\
\hline Volia - Cable Ltd. & 2016 & Non-GRI & + & - & s & 2 & 1 & 1 & 4 & Starters \\
\hline ViDi Group Holding & 2005-2010 & Non-GRI & - & - & Unacceptable & 1 & 1 & 1 & 3 & Outsiders \\
\hline
\end{tabular}

Note: "+" - the information is disclosed in report; “-" - information is not available, GRI - Global Reporting Standards (G - version of standards), IIRC - International Integrated Reporting Council. 


\section{APPENDIX B}

Table B1. Qualitative characteristics of companies' responsible behavior patterns by strategic benchmarks in achieving the SDGs, communication with stakeholders and approaches to information disclosure in the CSR reporting

Source: Compiled by authors on the basis of own research and Deloitte (2011), Ernst and Young (2012), Ernst and Young (2016).

\begin{tabular}{|c|c|c|c|c|c|c|c|}
\hline \multicolumn{2}{|c|}{ Cluster } & $\mathbf{F}$ & $\mathbf{E}$ & D & C & B & A \\
\hline \multicolumn{2}{|c|}{ Pattern } & "Companies -outsiders" & "Companies - starters" & "Companies - followers" & "Companies - pursuers" & "Companies - leaders" & "Companies - innovators" \\
\hline \multicolumn{2}{|c|}{$\begin{array}{l}\text { Strategies on SDGs } \\
\text { incorporation }(z)\end{array}$} & \multicolumn{2}{|c|}{$\begin{array}{l}\text { Compliance with the requirements of regulators on the } \\
\text { implementation of basic measurements, criteria and } \\
\text { principles of sustainability into company's activities }\end{array}$} & $\begin{array}{l}\text { Incorporating the principles } \\
\text { of sustainability and certain } \\
\text { SDGs inherent in industry } \\
\text { practice in the context of } \\
\text { the key risks of value loss }\end{array}$ & $\begin{array}{l}\text { Incorporating } \\
\text { the principles of } \\
\text { sustainability and certain } \\
\text { SDGs inherent in industry } \\
\text { practice in the context } \\
\text { of increasing the value of } \\
\text { the company }\end{array}$ & $\begin{array}{l}\text { Implementation of } \\
\text { relevant SDGs, integrated } \\
\text { risk management and the } \\
\text { benefits of sustainability to } \\
\text { increase the value }\end{array}$ & $\begin{array}{l}\text { The dimensions of } \\
\text { sustainability and the SDGs are } \\
\text { integrated into the company's } \\
\text { value formation strategy and } \\
\text { allow companies to create } \\
\text { additional innovations. }\end{array}$ \\
\hline \multirow[b]{2}{*}{$\begin{array}{l}\text { Interac- } \\
\text { tion } \\
\text { with } \\
\text { stake- } \\
\text { holders } \\
\text { (x) }\end{array}$} & \multirow{2}{*}{$\begin{array}{l}\text { Levels } \\
\text { Channels }\end{array}$} & \multicolumn{2}{|c|}{$\begin{array}{l}\text { The first level is the passive level of interaction, the model } \\
\text { of engagement of reactive type }\end{array}$} & \multicolumn{2}{|c|}{$\begin{array}{l}\text { The second level is bilateral interaction, models of } \\
\text { planned and systematic engagement }\end{array}$} & \multicolumn{2}{|c|}{$\begin{array}{l}\text { The third level is bilateral interaction, the model of } \\
\text { integrated engagement of proactive type }\end{array}$} \\
\hline & & $\begin{array}{l}\text { Letters, website, } \\
\text { complaints mechanisms, } \\
\text { "second hand reporting", } \\
\text { Internet-, media-, social } \\
\text { media - tracking }\end{array}$ & $\begin{array}{l}\text { Bulletins, letters, brochures, } \\
\text { presentations, conferences, } \\
\text { speeches, public presentations, } \\
\text { lobbying and defending the } \\
\text { interest }\end{array}$ & $\begin{array}{l}\text { Grant projects and } \\
\text { agreements, public and } \\
\text { private partnerships, } \\
\text { private financial initiatives, } \\
\text { collective agreements, } \\
\text { reporting }\end{array}$ & $\begin{array}{l}\text { Surveys, focus groups, } \\
\text { seminars, meetings with } \\
\text { individual stakeholders, } \\
\text { public meetings, } \\
\text { collective agreements, } \\
\text { research, reporting }\end{array}$ & $\begin{array}{l}\text { Advisory committees, } \\
\text { project reporting, } \\
\text { road shows, consensus } \\
\text { building processes, } \\
\text { multistakeholder forums, } \\
\text { advisory panels, reporting }\end{array}$ & $\begin{array}{l}\text { Participatory decision- } \\
\text { making process, joint projects } \\
\text { and events, integration of } \\
\text { stakeholders into management, } \\
\text { strategy and current activities } \\
\text { of the company, reporting }\end{array}$ \\
\hline \multicolumn{2}{|c|}{ Communication $(y)$} & $\begin{array}{l}\text { Passive strategy } \\
\text { Monitoring strategy }\end{array}$ & $\begin{array}{l}\text { Defensive strategy } \\
\text { Communication strategy }\end{array}$ & $\begin{array}{l}\text { Transactional strategy } \\
\text { Negotiation strategy }\end{array}$ & $\begin{array}{l}\text { Advisory strategy } \\
\text { Negotiation strategy }\end{array}$ & Engagement strategy & $\begin{array}{l}\text { Collaboration strategy } \\
\text { Strategy of capabilities } \\
\text { broadening }\end{array}$ \\
\hline \multicolumn{2}{|c|}{ CSR reporting $(y)$} & $\begin{array}{l}\text { Minimum disclosure of } \\
\text { information within the } \\
\text { annual report on the } \\
\text { established requirements } \\
\text { without reference to the } \\
\text { information needs of } \\
\text { particular stakeholders }\end{array}$ & $\begin{array}{l}\text { Disclosure of particular issues } \\
\text { of the use of the capital by } \\
\text { the company according to the } \\
\text { established requirements in } \\
\text { single-aspect non-financial } \\
\text { reports without taking into } \\
\text { account the needs of particular } \\
\text { stakeholders }\end{array}$ & $\begin{array}{l}\text { Environmental and social } \\
\text { reports, CSR reporting } \\
\text { that reflect both the } \\
\text { established disclosure } \\
\text { requirements and voluntary } \\
\text { disclosures with minimum } \\
\text { consideration of the needs } \\
\text { of stakeholders }\end{array}$ & $\begin{array}{l}\text { Reporting that reflects } \\
\text { all measurements and } \\
\text { criteria for sustainability } \\
\text {, taking into account the } \\
\text { most significant inquires } \\
\text { of stakeholders }\end{array}$ & $\begin{array}{l}\text { Comprehensive, balanced } \\
\text { disclosure of information } \\
\text { on all types of capital and } \\
\text { their role in creating value, } \\
\text { taking into account the } \\
\text { process of prioritizing the } \\
\text { inquires of stakeholders }\end{array}$ & $\begin{array}{l}\text { Integrated reporting- } \\
\text { disclosure of information on } \\
\text { all types of capital that the } \\
\text { company uses to create added } \\
\text { value in areas determined } \\
\text { during the interaction with } \\
\text { stakeholders }\end{array}$ \\
\hline \multicolumn{2}{|c|}{ Confirmation $(y)$} & Regulatory compliance & $\begin{array}{l}\text { Regulatory compliance, } \\
\text { separate audits within the } \\
\text { internal control system }\end{array}$ & $\begin{array}{l}\text { Separate audits within the } \\
\text { internal audit service }\end{array}$ & $\begin{array}{l}\text { Comprehensive } \\
\text { verification by the } \\
\text { internal audit service }\end{array}$ & $\begin{array}{l}\text { Independent external } \\
\text { confirmation by auditors } \\
\text { on the providing of a } \\
\text { private report }\end{array}$ & $\begin{array}{l}\text { Public external independent } \\
\text { confirmation, verification by } \\
\text { stakeholders }\end{array}$ \\
\hline
\end{tabular}

